\title{
Autochthonous falciparum malaria possibly transmitted by luggage-carried vector in Paris, France, February 2013
}

S Gallien (sebastien.gallien@sls.aphp.fr) ${ }^{1}$, F Taieb ${ }^{1}$, S Hamane ${ }^{2}$, N De Castro ${ }^{1}$, J M Molina ${ }^{1}$

1. Department of Infectious and Tropical Diseases, Paris Diderot University, Paris 7, Saint-Louis Hospital, Paris, France

2. Department of Parasitology, Paris Diderot University, Paris 7, Saint-Louis Hospital, Paris, France

We report a case of autochthonous falciparum malaria in a patient in Paris, France, in February 2013 who reported no recent travel to malaria-endemic countries. The parasite, Plasmodium falciparum, was possibly transmitted by an infective Anopheles mosquito carried in baggage from a malaria-endemic area.

\section{Case report}

A man in his early 40 s living in the outskirts of Paris, France, was admitted to our hospital's infectious disease department in February 2013 with fever and malaise. He reported a two-week course of fever, muscle stiffness, sweating episodes and headaches. He had also had a chronic cutaneous scalp lesion for 10 years: a biopsy two years ago demonstrated a discoid lupus erythematosus. This lesion was stable and had been never treated.

At admission, his temperature was $38.1{ }^{\circ} \mathrm{C}$, and his blood pressure and heart rate were normal. Physical examination showed a slight spleen enlargement and the previously identified indurated scaly plaque on the scalp with alopecia. Laboratory analysis revealed a white blood cell count of $2,830 / \mathrm{mL}$ (norm: $4,000-$ $10,000 / \mathrm{mL}$ ), with $1,710 / \mathrm{mL}$ polymorphonuclear cells (norm: $1,700-8,000 / \mathrm{mL}$ ). His haemoglobin level was $13.7 \mathrm{~g} / \mathrm{dL}$ (norm: $13-17 \mathrm{~g} / \mathrm{dL}$ ) and the platelet count was low, at 116,000/mL (norm: 150,000-450,000). Blood and urine cultures were sterile. Human immunodeficiency virus (HIV) serology was negative. Unexpectedly, microscopy of a blood smear showed a few trophozoites of Plasmodium parasites (parasitaemia $<0.01 \%$ ). A diagnosis of falciparum malaria was confirmed by microscopic examination (blood smear observation, thick and thin films) and an antigenic test (BinaxNOW Malaria, Inverness Medical Innovations, Scarborough, ME, United States). He was treated with atovaquoneproguanil according to the World Health Organization (WHO) guidelines (i.e. $1000 \mathrm{mg}$ atovaquone plus 400 $\mathrm{mg}$ proguanil once a day for three days) [1] and his symptoms resolved within two days.
He had no history of travel to malaria-endemic areas since he arrived in France in 2007 and he reported having not been in any airport since then. He lived in a migrant workers' hostel in the outskirts of Paris and also worked in this area, in locations that were more than $20 \mathrm{~km}$ from the nearest airport. He had no history of blood transfusion, tissue or organ transplantation, intravenous drug use, or fever in the previous six years.

He reported that a month before hospitalisation, he had shared his hostel room for two days with a friend who had just arrived from a malaria-endemic country in West Africa and who then left France for another country,. This man, who seemed healthy, travelled with luggage that had been opened for the first time since his arrival in France in presence of the patient during his stay in the hostel. No other hostel residents reported any febrile episodes during the six months since the luggage was opened.

We strongly suspected carriage of infective Anopheles mosquitoes in the man's baggage to be responsible for this case of malaria, even though no entomological study was performed to identify the source of the parasite. We reported this case as autochthonous malaria to the French Health Department for National Health Surveillance.

\section{Background}

The WHO defines autochthonous malaria as that acquired locally by a mosquito bite $[2,3]$.

In areas where malaria is not endemic, the most frequent subclass of autochthonous malaria is referred to 'airport malaria', where the parasite is transmitted by airplane-carried indigenous infective Anopheles to people usually living and/or working around airport areas [4].

Rarely, autochthonous malaria has been reported in people who had not entered an airport recently and had never travelled to malaria-endemic areas, but for 
whom transmission was suspected to arise from an infective vector brought after second transport through cars or luggage from the aircraft to the site of transmission [5].

\section{Discussion}

Luggage has occasionally been suspected of harbouring indigenous infective Anopheles from an endemic area, possibly causing infections when opened at arrival, as previously reported in Europe: in France (1995), Italy (1989) and Germany (1999) [5-7].

For our patient, other possible hypotheses of the origin of the parasite were ruled out by careful questioning of the patient. Misdiagnosis was excluded by extensive microbiological testing for other pathogens and confirmation of falciparum malaria by microscopic and antigen detection. The patient's condition also quickly resolved with atovaquone-proguanil, with no relapse after six months of follow-up.

Firstly, the infection was not acquired abroad. The patient originated from a malaria-endemic country, but had not been there for six years, nor had he travelled to other endemic areas during this period. In addition, both microscopic examination and antigenic testing were consistent with falciparum malaria, excluding long-lasting or relapsing malaria due to other Plasmodium species such as ovale, vivax or malariae.

Transmission not due to mosquitoes - e.g. through blood transfusion or tissue or organ transplantation was also excluded, given the patient's medical history.

Secondly, we hypothesised that the case was acquired locally. First-generation local transmission by local mosquitoes that is epidemiologically linked to a proven imported malaria case is unlikely. Although 13 Anopheles species have been reported in metropolitan France, anopheline malaria vectors have not been found resting or breeding in and around Parisian airports [8]. Moreover, the timing of both the presumed transmission and the clinical infection was during the coolest period of the year in France (i.e. winter), thus excluding the hypothesis that a potential autochthonous anopheline vector could have been infected by a gametocyte carrier in the Paris area. No entomological study was carried out in the hostel after reporting of the case.

We suppose, but cannot definitively conclude, that this patient was infected by an infective Anopheles vector imported into the country. In this scenario, malaria transmission among airport employees or residents living near airports serving airplanes from malariaendemic countries, and also in people living at some distance from the airport after secondary transport of the vectors by cars of airline employees, would be unlikely.
Finally, we hypothesise that the infective mosquito vector was brought in the luggage of the man travelling from a malaria-endemic country and that the mosquito bit the patient in their shared room, assuming that the vectors inside the luggage had escaped the WHOrecommended disinsection procedures for aircraft (assuming the recommended disinsection procedures had been performed) [4].

We note that the mode of transmission of all reported cases of autochthonous falciparum malaria in France were also not proven $[5,9,10]$.

In clinical practice, locally acquired luggage malaria should be suspected in patients with fever of unknown origin who have been in close contact with people who have just returned from malaria-endemic areas.

\section{Conflict of interest}

None declared.

Authors' contributions

SG, FT, NDC and JMM took part in the clinical management of the patient. SH made the parasitological diagnosis and contributed to the epidemiological investigation. SG wrote the manuscript, which was reviewed by all the authors. All authors read and approved the final manuscript.

References

1. World Health Organization (WHO). Guidelines for the treatment of malaria. 2nd edition. Geneva: WHO; 2010. Available from: http://whqlibdoc.who.int/publications/2010/9789241547925 eng.pdf

2. Kelly M. Terminology of malaria and of malaria eradication. Lancet. 1964;1(7325):157-8. PMid:14074492.

3. Classification. In: Guidelines on the elimination of residual foci of malaria transmission. Cairo: World Health Organization Regional Office for the Eastern Mediterranean (EMRO); 2007. EMRO Technical Publications Series 33. p. 46-7 (Annex 1). Available from: http://applications.emro.who.int/dsaf/dsa742. pdf

4. Gratz NG, Steffen R, Cocksedge W. Why aircraft disinsection? Bull World Health Organ. 2000;78(8):995-1004. PMid:10994283 PMCid:PMC2560818

5. Guillet P, Germain MC, Giacomini T, Chandre F, Akogbeto $M$, Faye 0 , et al. Origin and prevention of airport malaria in France. Trop Med Int Health. 1998;3(9):700-5. http://dx.doi. org/10.1046/j.1365-3156.1998.00296.x. PMid:9754664.

6. Rizzo F, Morandi N, Riccio G, Ghiazza G, Garavelli P. Unusual transmission of falciparum malaria in Italy. Lancet. 1989;1 (8637):555-6.

http://dx.doi.org/10.1016/S0140-6736(89)90095-0

7. Praetorius F, Altrock G, Blees N, Schuh N, Faulde M. [Imported Anopheles: in the luggage or from the airplane? A case of severe autochthonous malaria tropica near an airport]. Dtsch Med Wochenschr. 1999;124(34-35):998-1002. German. http:// dx.doi.org/10.1055/s-2007-1024464. PMid:10488327.

8. Schaffner F, Angel G, Geoffroy B, Hervy JP, Rhaiem A, Brunhes $J$. The mosquitoes of Europe. An identification and training programme [CD-ROM]. Montpellier: IRD Éditions \& EID Méditerrannée; 2001.

9. Pomares-Estran C, Delaunay P, Mottard A, Cua E, Roger PM, Pradines B, et al. Atypical aetiology of a conjugal fever: autochthonous airport malaria between Paris and French Riviera: a case report. Malar J. 2009;8:202. http://dx.doi. org/10.1186/1475-2875-8-202. PMid:19698152. PMCid:PMC2734347.

10. Baixench MT, Suzzoni-Blatger J, Magnaval JF, Lareng MB, Larrouy G. [Two cases of inexplicable autochthonous malaria in Toulouse, France]. Med Trop. 1998;58(1):62-4. French. 